\title{
Student Self-Assessment in Higher Education: The International Experience and the Greek Example
}

\author{
Anastasia Papanthymou ${ }^{1, *} \&$ Maria Darra ${ }^{1}$ \\ ${ }^{1}$ Department of Primary Education, University of the Aegean, Rhodes, Greece \\ *Correspondence: Department of Primary Education, University of the Aegean, Dimokratias 1, Rhodes, 85132, \\ Greece. Tel: 30-694-833-9499. E-mail: premnt15043@rhodes.aegean.gr
}

Received: December 4, 2018

Accepted: December 19, $2018 \quad$ Online Published: December 20, 2018

doi:10.5430/wje.v8n6p130

URL: https://doi.org/10.5430/wje.v8n6p130

\begin{abstract}
This study is a review of 34 empirical studies internationally and in Greece from 2008-2018 and aims at investigating: a. the implementation of student self-assessment in Higher education and the outcomes on students, b. the ability of students to self-assess accurately and the factors that affect this ability. According to the main findings, self-assessment is implemented through various ways that include inter alia electronic and non-electronic self-assessment tools. Internationally, most studies have examined and proved the contribution of student self-assessment to improvement of performance and learning. Moreover, self-assessment develops self-regulating learning, increases self-confidence, motivates students to ask guidance from their professors and help from their peers, increases self-efficacy, students' awareness of self-assessment ability and self-control, makes students change attitudes towards course, prepares employability skills of students, reduces anxiety for assessment, increases students' responsibility about their learning, makes them have a critical view on their work and develops critical thinking skills. In Greece, it was found only one study that examined the implementation of student self-assessment in Higher education and its impact on students and findings indicate that self-assessment through a quiz improves performance, self-regulation, motivates students to try more and helps them identify gaps in their learning. Student self-assessment ability and factors that affect this ability have been examined only internationally, so in Greece there is a research gap concerning these parameters. Tertiary students can self-assess accurately and this ability depends on specific factors such as confidence, prior achievement, learning style, scaffolding from professors, training, dialogical interaction and dynamic assessment.
\end{abstract}

Keywords: accuracy, benefits of student self-assessment, higher education, self-assessment ability, student self-assessment

\section{Introduction}

Educational assessment has been a prominent element of education in recent years (Keane \& Griffin, 2016). Nowadays, assessment in Higher education moves from conventional testing to learning evaluation (Logan, 2015) and has specific goals. Specifically, it introduces methods that are effective, promotes learning, motivates students, protects and defines academic standards, measures the learning results with validity and reliability, emphasizes on the achievement of individual students and focuses on learning (Li \& Chen, 2016). Increasingly, teachers are called to involve students in the assessment procedures (Logan, 2015). According to Langan et al. (2008) self and peer assessment are very important skills for professional development and lifelong learning, so there is an increasing interest for including them in Higher education assessment. Especially, student self-assessment is one of the basic field of study in education psychology and contemporary education (Panadero, Jonsson, \& Botella, 2017). Despite the fact that student self-assessment can play a very basic role in development of professional ability and in learning and leads to the increased interest of educators and researchers for this type of assessment (Lew, Alwis \& Schmidt, 2010), it seems that it is not very popular for several reasons. First, students consider that teachers are responsible for the assessment process. Second, teachers don't trust students for judging and third, students don't have the ability to self-assess (Thawabieh, 2017).

The ability of students to self-assess their work has been one of the implicit goals in Higher education (Boud, Lawson \& Thompson, 2013). The intention of self-assessment is to make students be active learners and reflect on 
their learning outcomes, styles and processes (Topping, 2003). Teachers should know how self-assessment can be a key process in any learning activity and students need understand their role as agents within the learning and assessment procedure and commit to be realistic in their self-assessments (Harris \& Brown, 2018).

According to literature review of Sluijsmans, Dochy, \& Moerkerte (1999) tertiary students have the ability to self-assess accurately. Accuracy of student self-assessment is very important so steps should be taken to maximize it (Harris \& Brown, 2018). Feedback, ability of student, practice, differences in gender and culture, the nature of the assessment criteria, assessment tools, assessed subject and performance, the degree of scaffolding and advancement in a task affect the accuracy of student self-assessment (Topping, 2003). Still, Ross (2006) supports that specific student training contribute to the enhancement of the strength of student self-assessment. Moreover, Harris and Brown (2018) argue that self-assessment is a complicated practice to implement successfully in the class. Andrade and Valtcheva (2009) underline some factors that are important for successful implementation of student self-assessment such as teaching the application of criteria to students for assessing their work, the provision of efficient time to students to revise their work after the procedure of self-assessment, the provision of feedback and help to students and the definition of criteria that students use for assessing their work.

The literature review shows that self-assessment has positive outcomes for students. Specifically, student self-assessment improves performance, enhances lifelong and deep learning, social competencies, makes students participate in learning, develops their autonomy, make them feel that they can control their own assessment and decreases student anxiety. Furthermore, self-assessment prepares students for a democratic society and improves cognitive (Wride, 2017), metacognitive abilities (Topping, 2003; Wride, 2017), performance (Rolheiser \& Ross, 2001; Ross, 2006) and enhances self-efficacy (Rolheiser \& Ross, 2001) and motivation (Rolheiser \& Ross, 2001; McMillan \& Hearn, 2008). Furthermore, self-assessment helps students identify strengths and weaknesses of their work (Ross, 2006). Besides, self-assessment is a procedure where students can provide feedback to themselves and decide for the following steps to enhance their performance (McMillan \& Hearn, 2008). According to Alonso-Tapia and Panadero (2010) there are not many studies that examine the impact of student self-assessment on self-regulation.

The contribution of this literature review is to provide evidence for student self-assessment in Higher education. Especially, the aim of this paper is to summarize and provide feedback on the recent studies on student self-assessment in Higher education all over the world over the last decade (2008-2018). This paper can provide professors with useful evidence about student self-assessment concerning implementation ways and tools, the factors that are crucial for effective implementation of student self-assessment, the positive outcomes for students and the ability of students to self-assess. Moreover, this study identifies gaps internationally and in Greek Higher education and makes proposal for further research. The present study includes the following sections: the theoretical framework, the aim of the study and the research questions, the method, the results, the discussion of the main findings, conclusions, implications and proposals for further research.

\section{Theoritical Framework}

Self-assessment is a procedure where students judge the quality of their own work according to specific criteria for improving their work in the future (Rolheiser \& Ross, 2001). Students judge their own learning and achievement and decide about action for future progress in learning (Sebba et al., 2008). It is an act where students describe and assess their academic abilities and work (Harris \& Brown, 2018). They collect information and compare their progress or performance to specific criteria or goals and revise their work based on these criteria or goals (Andrade \& Valtcheva, 2009). Moreover, self-assessment helps students not only describe but also evaluate their work and it is a very important element of current conceptions of formative assessment (Brown, Andrade, \& Chen, 2015).

Self-assessment is a type of assessment that refers to the involvement of students in expressing their view of learning, and particularly their achievements and learning outcomes. Hence, self-assessment is a way of enhancing the role of students as active participants in their learning and it is usually used as a formative assessment that helps students reflect on their learning processes and outcomes (Sluijsmans et al., 1999). Student self-assessment is qualitative assessment of the learning procedure and of its results, based on predefined quality criteria and it doesn't focus on the score, but on understanding this procedure, where the students can learn from their mistakes and achievements. Therefore, self-assessment is a reflection process (Panadero \& Alonso-Tapia, 2013).

Petropoulou, Kasimati \& Retalis (2015: 131) suggest the following stages of student self-assessment.

- Explanation of the goals per learning unit and link of them to the desired learning outcomes. 
- A clear explanation of the criteria to students and confirmation of their progress using examples.

- Description of the educational design in a detailed and clear way (means, flow of educational process, etc.).

- Implementation of self-assessment procedure for evaluating current progress of learning.

- Provide feedback to students to achieve the expected outcomes.

Furthermore, student self-assessment can be done with various ways, quantitatively, qualitatively or descriptively, so students acquire self-knowledge (Papageorgiou, 2017). In particular, student self-assessment includes a wide variety of mechanisms and techniques through which the students describe and evaluate the quality of learning procedure and its products (Panadero, Brown \& Strijbos, 2016). Finally, for implementing student self-assessment process there is a range of tools or techniques such as self-assessment checklists, scripts, templates, rubrics, self-marking, estimating future performance and self-assessment templates (Harris \& Brown, 2018).

\section{Aim of the Study and Research Questions}

The present paper is a review of 34 empirical studies and examines the topic of student self-assessment in Higher education in Greece and internationally the last decade (2008-2018). Specifically, the main purpose of this study is to investigate: a. the implementation tools of student self-assessment and the benefits that self-assessment has on students, b. the student self-assessment ability and the factors that affect this ability. Also, this study identifies gaps and makes proposals for further research.

The research questions that this review aims to answer are:

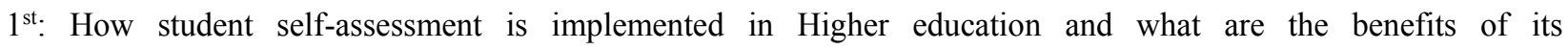
implementation?

$2^{\text {nd. }}$ Can students self-assess accurately and what are the factors that affect this ability?

\section{Method}

Table 1 presents the assessment criteria we used for selecting studies.

Table 1. Assessment Criteria for Studies

\begin{tabular}{ll}
\hline Assessment criteria for studies & \\
\hline Research questions & a) How student self-assessment is implemented in Higher \\
& b) Can students self-assess accurately and what are the factors \\
& that affect this ability? \\
Geographical distribution & Global \\
Year of publication & 2008-2018 \\
Language & Greek, English \\
Type of studies & Empirical studies \\
\hline
\end{tabular}

Figure 1 shows the steps of methodology we followed. 


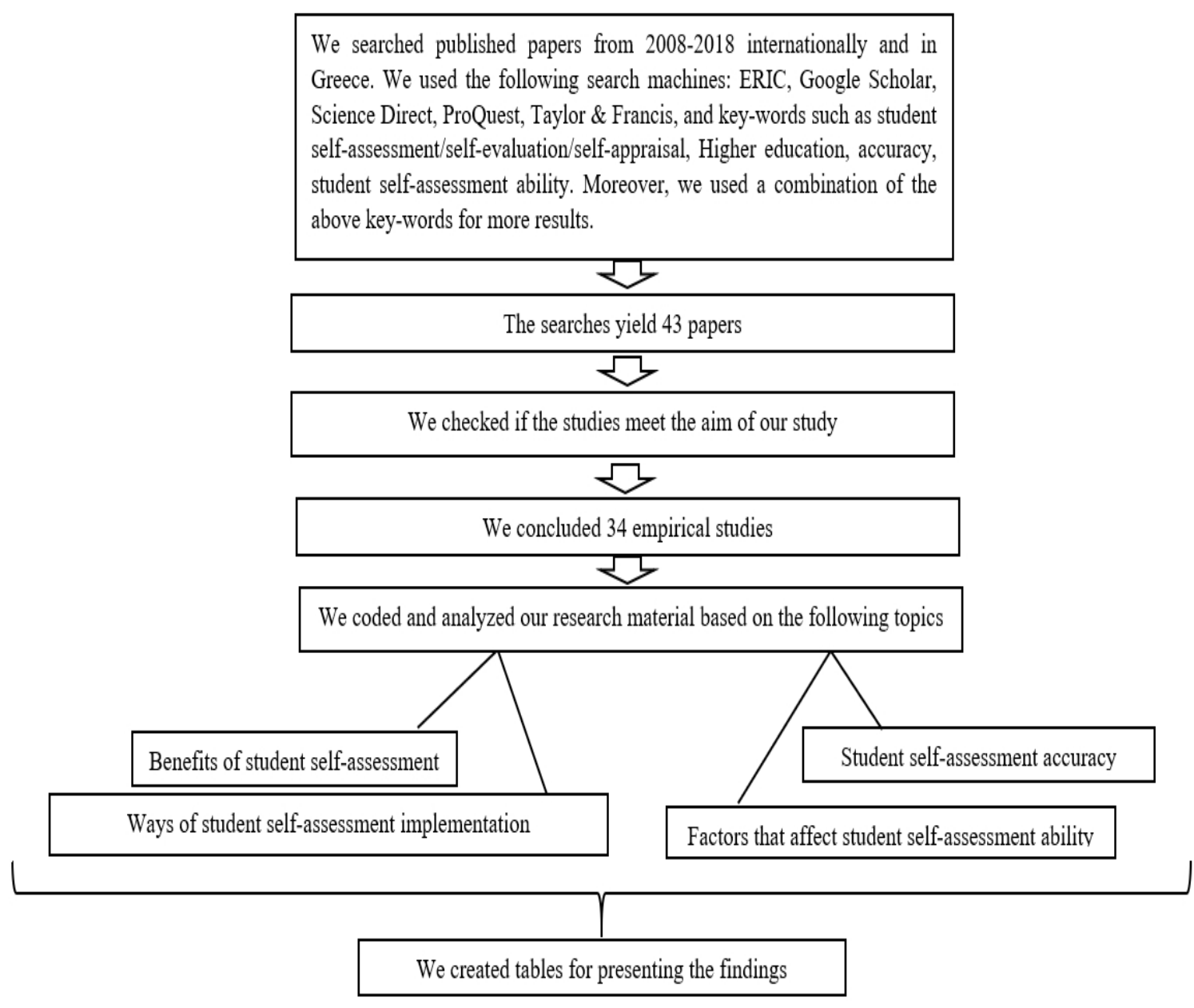

\section{Results}

Figure 1. Methodology

Figure 2 presents the number of examined empirical studies in Greece and internationally.

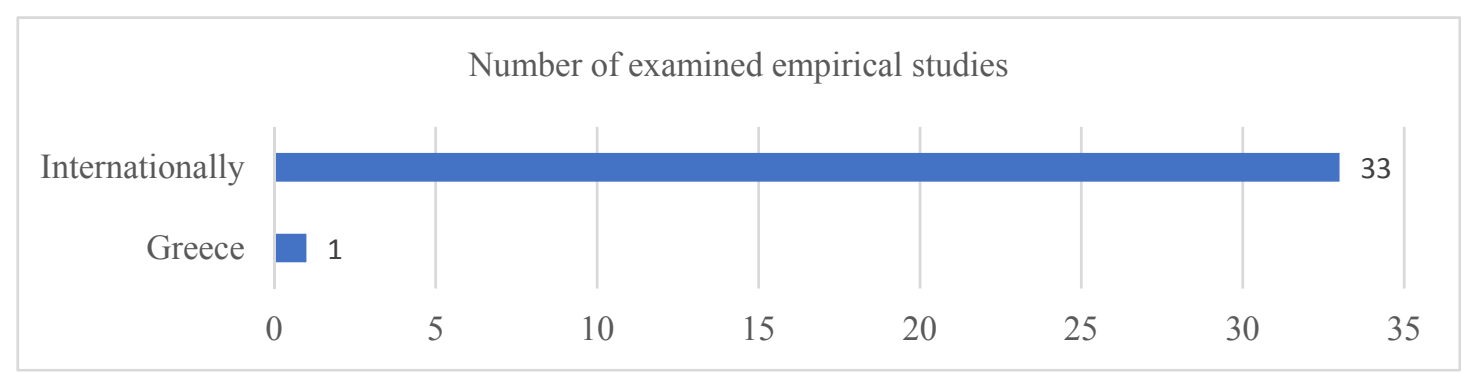

Figure 2. Number of Examined Empirical Studies

Figure 3 shows the number of studies per year from 2008-2018. 


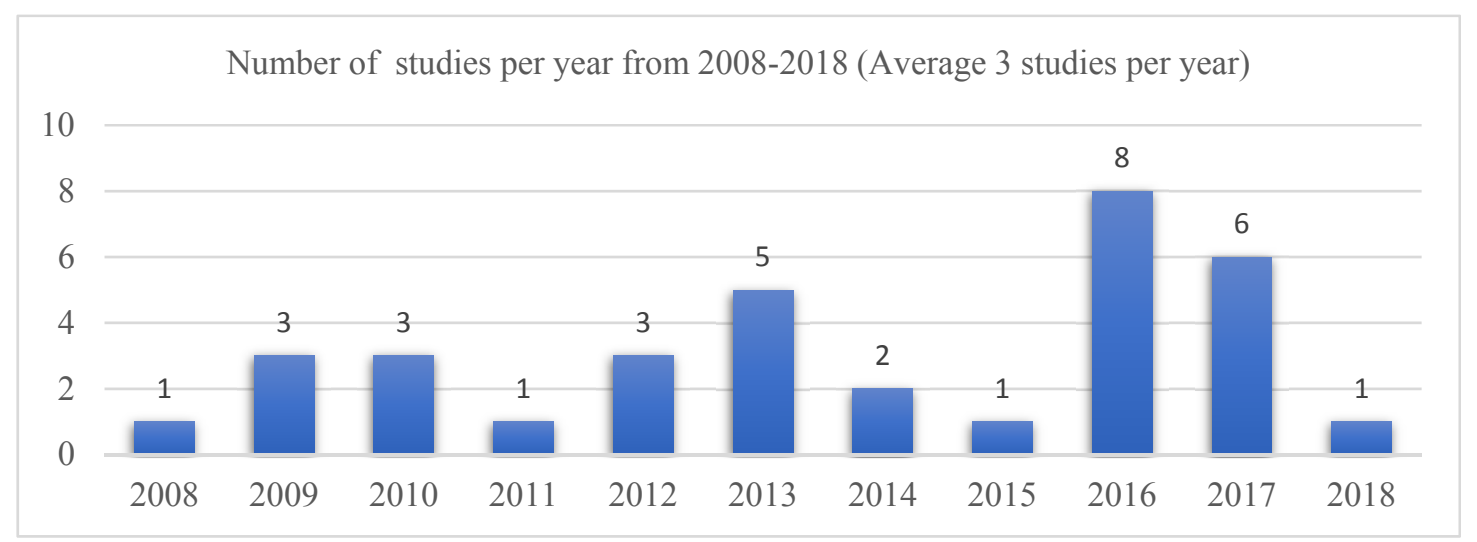

Figure 3. Number of Studies per Year from 2008-2018

Figure 4 shows the number of studies per country.

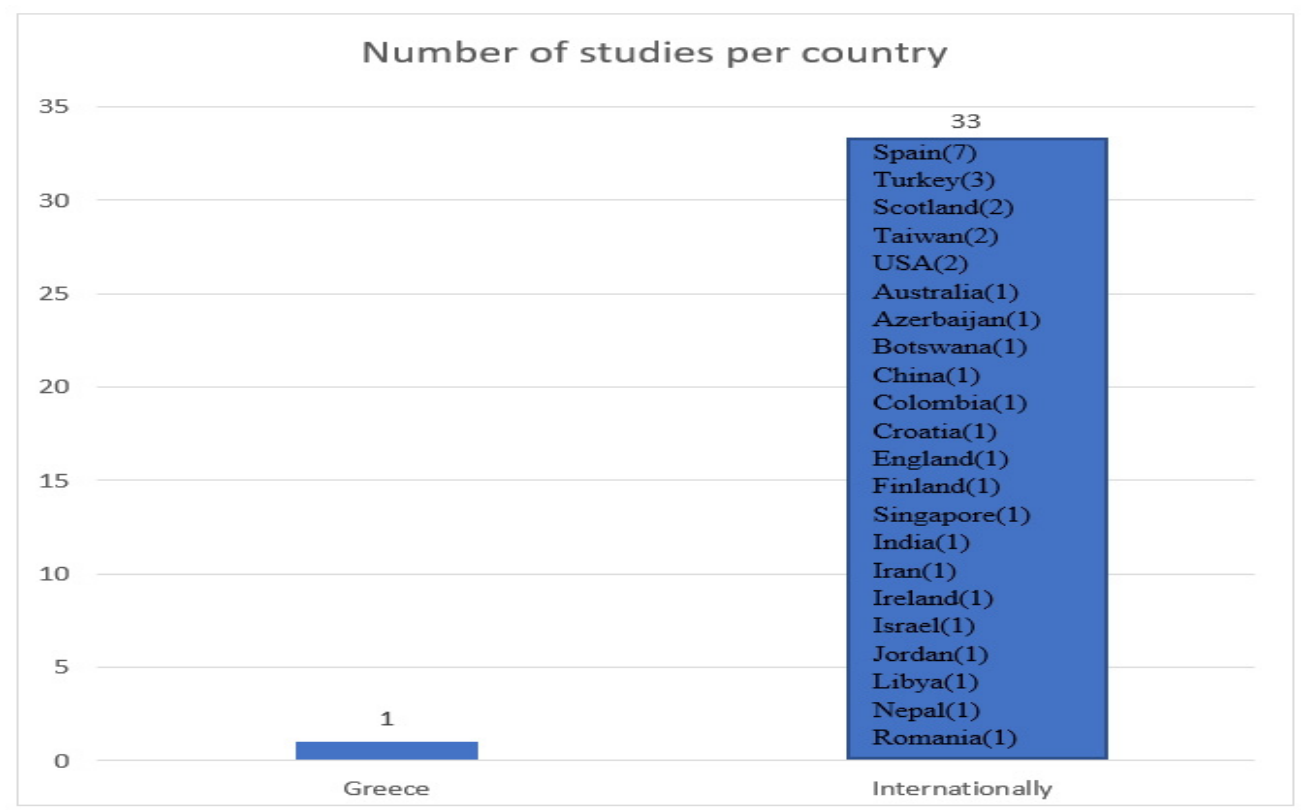

Figure 4. Number of Studies per Country

Research question 1: How student self-assessment is implemented in Higher education and what are the benefits of its implementation?

Table 2 presents how self-assessment is implemented in Higher education and the benefits of its implementation. 
Table 2. Ways of Implementation of Student Self-Assessment in Higher Education and Benefits on Students

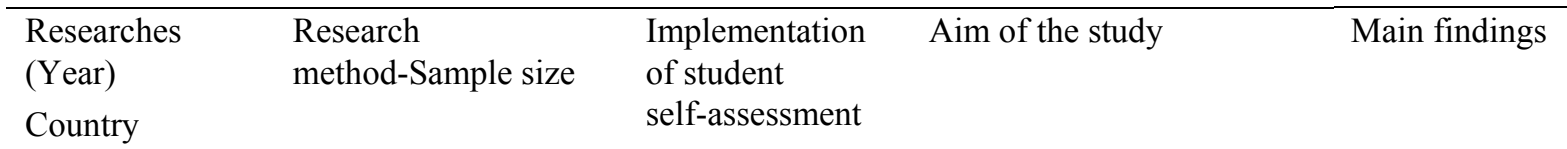

1. Hung (2009) Qualitative case study E-portfolio
Taiwan (2 students)

2. Leaf et al. (2009)

Quantitative research

USA

3. Pournias

(2009)

Quantitative research

Greece
Quiz (Quiz report analysis for moodle)
On line self-assessment tool
Investigation of how foreign language students use self-assessment when they write in their e-portfolios.

Investigation of the effectiveness of an online self-assessment tool to a traditional curriculum for $2^{\text {nd }}$ year students in medical education.

Development of the Quiz Report Analysis to present the results of student self-assessment through Quiz module of Moodle.
E-portfolio promotes student self-assessment practice and encourages self-directed language learning.

On line self-assessment tool fills knowledge gaps, enhances learning, improves performance and provides opportunities to practice exam questions.

The Quiz report analysis enables students to get feedback on their performance in each test, compare their performance with that of their peers, assess their level of knowledge and have a picture of their learning. In addition, this tool helps students improve their performance, and self-regulation. Still, it motivates the students to try more and helps them identify gaps in their learning.

The use of interactive assessment improves academic performance. Still, students with low motivation levels used self-assessment material.

Students expressed the opinion that their performance has been improved significantly.
Self-assessment system helped students in their preparation for the test. Moreover, students found it useful and noticed that it helped them in their individual learning.
Mobile Assessment Participation System

\begin{tabular}{|c|c|c|c|}
\hline $\begin{array}{l}\text { 4. Ibabe \& } \\
\text { Jauregizar } \\
(2010) \\
\text { Spain }\end{array}$ & $\begin{array}{l}\text { Non-experimental } \\
\text { research method (116 } \\
\text { students) }\end{array}$ & $\begin{array}{l}\text { Self-assessment } \\
\text { material with } \\
\text { Hot-Potatoes }\end{array}$ & $\begin{array}{l}\text { Development of } \\
\text { self-assessment material } \\
\text { with Hot-Potatoes and } \\
\text { evaluation of the extent to } \\
\text { which this material has a } \\
\text { beneficial effect on } \\
\text { students. }\end{array}$ \\
\hline $\begin{array}{c}\text { 5. Chen }(2010) \\
\text { Taiwan }\end{array}$ & $\begin{array}{l}\text { Quantitative research } \\
\text { (37 students) }\end{array}$ & $\begin{array}{l}\text { Web-based } \\
\text { Mobile } \\
\text { Assessment } \\
\text { Participation } \\
\text { System }\end{array}$ & $\begin{array}{l}\text { Proposal of a web based } \\
\text { system that can contribute } \\
\text { to the effectiveness of self } \\
\text { and peer-assessment. }\end{array}$ \\
\hline $\begin{array}{l}\text { 6. Antal \& } \\
\text { Koncz (2011) } \\
\text { Romania }\end{array}$ & $\begin{array}{l}\text { Quantitative research } \\
\text { (10 students) }\end{array}$ & $\begin{array}{l}\text { On line } \\
\text { self-assessment } \\
\text { system }\end{array}$ & $\begin{array}{l}\text { Development of a } \\
\text { self-assessment system and } \\
\text { monitoring its use by } \\
\text { students. In addition, } \\
\text { proposal of a graphic that } \\
\text { presents students' } \\
\text { knowledge and provides a } \\
\text { more detailed graphical }\end{array}$ \\
\hline
\end{tabular}

Development of self-assessment materia with Hot-Potatoes and evaluation of the extent to which this material has a beneficial effect on students.

Proposal of a web based system that can contribute to the effectiveness of self and peer-assessment.

Development of a self-assessment system and monitoring its use by students. In addition, proposal of a graphic that presents students' knowledge and provides a more detailed graphical

\author{
.
}


depiction of the progress of student knowledge over time.

$\begin{array}{cl}\text { 7. Tai (2012) } & \begin{array}{l}\text { Mixed methods } \\ \text { research design with } \\ \text { sequential explorative } \\ \text { design } \\ \text { (251questionnaires } \\ \text { and 18 interviews } \\ \text { with students) }\end{array} \\ & \begin{array}{l}\text { Quasi-experimental } \\ \text { design (54 students) }\end{array} \\ \text { 8. Alishah, \& } & \\ \text { Dolmaci (2013) } & \\ \text { Turkey } & \text { Qualitative research } \\ \text { Suers (2013) } & \text { Scotland }\end{array}$

10. Panadero, Experimental research Alonso-Tapia, (69 students) \& Reche (2013) Spain

11. Wolffensperger \& Patkin (2013) Israel
Student self-assessment within the framework of Biggs' 3P learning model.

Continuous self-assessment

Peer review and self-assessment

Rubrics

Self-assessment scripts

Student self-assessment in a procedure of co-teaching
Investigation of self-assessment in a procedure of co-teaching.
Investigation of the result of continuous self-assessment on students' self-efficacy. Investigation of students' conceptions and implementation of peer review and self-assessment.

Comparison between the effect of rubrics and scripts on performance, self-efficacy and self-regulation. (17 students and 2 lecturers)
12. Ćukušić, Garača, \& Jadrić (2014)

Croatia

13. Panadero \& Romero (2014) Spain
Quantitative and comparative study (1.379 students)

Experimental research Rubric (Quasi-experiment, 218 students)

Online test self-assessment

Investigation of the effects of the online self-assessment tests on students.

Comparison between the effects of using rubrics for self-assessment and using no specific tool for self-assessment.
Self-assessment practice develops self-regulating learning and increases self-confidence.

Continuous self-assessment increases significantly self-efficacy.

Both peer review and self-assessment help students receive feedback on their knowledge, understanding and skills they have developed.

Scripts contribute to development of self-regulating learning but rubrics have a negative effect on it. Moreover, no significant effect has been found on self-efficacy or academic performance.

Self-assessment contributes to problem-solving. Moreover, it increases students' awareness of development of self-assessment ability and self-control. Moreover, self-assessment makes students change attitude towards the course and recognize the importance and contribution of it to their learning.

There is a link between the students' success and the online self-assessment.

Students who used rubrics mentioned higher accuracy, learning strategies use and higher performance but they faced more problems connected with stress and higher performance or avoidance self-regulation 
14. Bhandary,

Ghimire, \&

Shrestha (2016)

Mixed methods research design (58 students)

Nepal

15. Gurbanov (2016)

Azerbaijan

Quntitative research (31 professors, 100 students)

16. Ozarslan \& Ozan (2016)

Quantitative research (677 students)

Turkey

\section{Rivas \& Arrufat (2016) \\ Spain}

18. Li \& Chen (2016)

China

19. McKevitt (2016)

Ireland

20. Sharma et al. (2016) India
Mixed methods research design (35 students)

Quantitative research (89 students)
Web based self-assessment tool

Peer and self-assessment

Online self-assessment quiz taking behaviors

Electronic rubrics for self and peer assessment

Self and peer-assessment

Exemplars, self-assessment, criteria, feedback

Self-assessment
Investigation of students' and professors' beliefs about the grading in student peer and self-assessment.

Investigation the student self-assessment quiz taking behaviors in an online course.

Investigation of the use of erubrics to assess learning.

Investigation of peer and self-assessment as effective tools that can cause a change in the way of student learning.

Investigation of how student self-assessment and feedback from tutor influence students' performance and assessment ability. Examination of students' experience.

Investigation of the effect of student self-assessment on academic performance and examination of students' and professors' perceptions about self-assessment as a tool that contributes to that influenced learning negatively.

Web based self-assessment tool makes students self-access continuously and motivates them to ask guidance from their professors and help from their peers. Still, it encourages life-long and self-directed learning habits.

Peer and self-assessment reduce anxiety for assessment, increase students' responsibility about their learning and make students have a critical eye on their work and on the work of their peers.

Students who used the self-assessment quiz taking behaviors frequently were more satisfied with the course, had higher degree of perceived learning and higher scores in the final exam.

Erubrics reinforce academic performance, learning and promote responsibility.

Peer and self-assessment shift student learning methods from surface to deep approaches to learning and develop learning environment.

Students improved their performance in an assignment.

Self-assessment motivates students and makes them be more interested in subjects that lead to higher academic performance. Still, self-assessment enhances learning and contributes to the development of critical 


\begin{tabular}{|c|c|c|c|c|}
\hline & & & enhancement of learning. & skills. \\
\hline $\begin{array}{l}\text { 21. Duque } \\
\text { Micán \& Cuesta } \\
\text { Medina (2017) } \\
\text { Colombia }\end{array}$ & $\begin{array}{l}\text { Mixed methods } \\
\text { research design ( } 24 \\
\text { students) }\end{array}$ & $\begin{array}{l}\text { Systematic cycle } \\
\text { where } \\
\text { self-assessment } \\
\text { is applied as a } \\
\text { formative } \\
\text { assessment } \\
\text { source }\end{array}$ & $\begin{array}{l}\text { Investigation of the effect } \\
\text { of self-assessment on } \\
\text { vocabulary ability on } \\
\text { students' oral fluency. }\end{array}$ & $\begin{array}{l}\text { Students became more able } \\
\text { to judge, self-monitored and } \\
\text { reacted towards their } \\
\text { learning and language gains. } \\
\text { They could set learning } \\
\text { commitments and identify } \\
\text { weaknesses and strengths in } \\
\text { their learning. Besides, } \\
\text { students used learning } \\
\text { strategies. }\end{array}$ \\
\hline $\begin{array}{l}\text { 22. Fraile, } \\
\text { Panadero, \& } \\
\text { Pardo (2017) } \\
\text { Spain }\end{array}$ & $\begin{array}{l}\text { Experimental research } \\
\text { (65 students) }\end{array}$ & $\begin{array}{l}\text { Co-creating } \\
\text { rubrics (students } \\
\text { take part in the } \\
\text { creation of } \\
\text { rubrics) }\end{array}$ & $\begin{array}{l}\text { Comparison between the } \\
\text { influence of co-creating } \\
\text { rubrics and use of rubrics } \\
\text { without the process of } \\
\text { co-creating. }\end{array}$ & $\begin{array}{l}\text { Co-creating rubrics may } \\
\text { activate learning strategies } \\
\text { and have a positive effect on } \\
\text { self-regulation and } \\
\text { performance. }\end{array}$ \\
\hline $\begin{array}{l}\text { 23. Elgadal } \\
\text { (2017) } \\
\text { Libya }\end{array}$ & $\begin{array}{l}\text { Experimental research } \\
\text { (100 students in Libya } \\
\text { and } 32 \text { Libyan } \\
\text { students who study in } \\
\text { England) }\end{array}$ & $\begin{array}{l}\text { Self-assessment } \\
\text { sheet, post-study } \\
\text { feedback form }\end{array}$ & $\begin{array}{l}\text { Investigation of the effect } \\
\text { of self-assessment on the } \\
\text { writing of EFL students. }\end{array}$ & $\begin{array}{l}\text { Most students who used } \\
\text { self-assessment had a } \\
\text { positive attitude towards the } \\
\text { procedure of self-assessment } \\
\text { and improved their drafts } \\
\text { because they made surface } \\
\text { and meaning revisions } \\
\text { whereas the students who } \\
\text { didn't use self-assessment } \\
\text { made a few surface } \\
\text { revisions. }\end{array}$ \\
\hline $\begin{array}{l}\text { 24. Machera } \\
\text { (2017) } \\
\text { Botswana }\end{array}$ & $\begin{array}{l}\text { Quantitative research } \\
\text { (90 students) }\end{array}$ & $\begin{array}{l}\text { Self and peer } \\
\text { assessment }\end{array}$ & $\begin{array}{l}\text { Investigation whether self } \\
\text { and peer assessment can } \\
\text { increase students' } \\
\text { possibilities for access to } \\
\text { employment. }\end{array}$ & $\begin{array}{l}\text { Self and peer assessment } \\
\text { give important feedback that } \\
\text { improves teaching. } \\
\text { Moreover, both self and peer } \\
\text { assessment contribute to } \\
\text { self-directing and prepare } \\
\text { employability skills of } \\
\text { students. }\end{array}$ \\
\hline $\begin{array}{l}\text { 25. Ndoye } \\
(2017) \\
\text { USA }\end{array}$ & $\begin{array}{l}\text { Qualitative research } \\
\text { (16 students) }\end{array}$ & $\begin{array}{l}\text { Self and peer } \\
\text { assessment }\end{array}$ & $\begin{array}{l}\text { Investigation of students' } \\
\text { perceptions about peer and } \\
\text { self-assessment procedures } \\
\text { and examination how these } \\
\text { procedures contribute to } \\
\text { their learning. }\end{array}$ & $\begin{array}{l}\text { Self and peer assessment } \\
\text { help students identify } \\
\text { learning gaps and fill these } \\
\text { gaps by developing } \\
\text { strategies. }\end{array}$ \\
\hline
\end{tabular}

Research question 2: Can students self-assess accurately and what are the factors that affect this ability?

The following table 3 presents student self-assessment ability and the factors that affect this ability. 
Table 3. Student Self-Assessment Ability and the Factors That Affect This Ability

\begin{tabular}{|c|c|c|}
\hline $\begin{array}{l}\text { Researchers } \\
\text { (Year) } \\
\text { Country }\end{array}$ & $\begin{array}{l}\text { Research method-Sample } \\
\text { size }\end{array}$ & Aim of the study \\
\hline $\begin{array}{l}\text { 1. Langan et al. } \\
(2008) \\
\text { Spain }\end{array}$ & $\begin{array}{l}\text { Quantitative research (60 } \\
\text { students) }\end{array}$ & $\begin{array}{l}\text { Investigation of the influence } \\
\text { of gender and level of } \\
\text { achievement on marks. }\end{array}$ \\
\hline $\begin{array}{l}\text { 2. Lew et al. } \\
(2010) \\
\text { Singapore }\end{array}$ & $\begin{array}{l}\text { Quantitative research ( } 2 \\
\text { studies, the sample size } \\
\text { of the first study was } \\
3.588 \text { students and the } \\
\text { sample size of the second } \\
\text { study was } 936 \text { students) }\end{array}$ & $\begin{array}{l}\text { Investigation of accuracy of } \\
\text { student self-assessment ability } \\
\text { and examination of the time as } \\
\text { a factor that may affect this } \\
\text { ability. Moreover, examination } \\
\text { if students' beliefs about the } \\
\text { utility of self-assessment, } \\
\text { influences accuracy. }\end{array}$ \\
\hline
\end{tabular}

\section{Chen (2010) Quantitative research (37 Proposal of a web based Taiwan system that can contribute to the effectiveness of self and peer-assessment.}

$\begin{array}{ll}\text { 4. Alaoutinen } & \text { Quantitative research } \\ \text { (2012) } & \text { (145 students) }\end{array}$

Finland

\section{Sasmaz Oren Quantitative research (2012)}

Turkey
Investigation of the factors that influence performance and self-assessment accuracy.

Investigation of the impact of a) prior students' experience upon self and peer assessment and b) gender, on scores.
6 . Boud et al. (2013) Australia
Quantitative (2.196 self-assessments, 182 students)

\section{7.}

Examination of the relationship between the voluntary participation of students in self-assessment and the students' ability to self-assess.
Main findings

Female students underestimated their performance when they self-assessed. Grades by peer assessment were more associated with the grades from professors than the grades from self-assessment. Moreover, students with low achievement over-marked themselves.

Students could assess themselves accurately to a limited extent. Moreover, students who are academically capable could self-assess with higher accuracy than students who are less capable. Accuracy of student self-assessment wasn't improved over time. There was no link between the accuracy of student self-assessment and students' beliefs about the utility of self-assessment process.

There was no consistency between professors' and students' grades. This may be happened because students received first feedback from their peers and then revised their work.

Students who are advanced are more able to self-asses accurately than students who are novices. Clearly visual, active, balanced sequential, and sensing students are more accurate.

Based on gender female students had higher mean scores than male students in all types of scoring. With regard to past experience there wasn't found any significant difference between students who had experience in examined assessment procedures and students who didn't have experience.

Overall students' assessments were aligned with those of professors, but weaker students had little improvement.

At the beginning of the process of 


\begin{tabular}{lll}
\hline Wolffensperger & students and 2 lecturers) & $\begin{array}{l}\text { self-assessment in a procedure } \\
\text { of co-teaching. }\end{array}$ \\
\& Patkin (2013) & &
\end{tabular}

Israel

\author{
9. Domínguez, Quantitative (97 \\ Jaime, Sánchez, students) \\ Blanco, \& Heras \\ (2016) \\ Spain \\ 10. McKevitt \\ (2016) \\ Mixed methods research \\ design (35 students)
} Ireland

\section{Sharma et al. Quantitative (89 (2016) students)}

India

12. Thawabieh

(2017)

Jordan

13. Hosein \& Harle (2018)

England

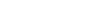

Investigation of EFL students' self-assessment and self-scoring of their writing competence and examination of the influence of dynamic assessment on students' self-assessment accuracy. Examination of the interrelationships among professors' scoring, self-scoring and self-assessment in the writing performance.

Investigation of the difference and consistency among online self, peer, external and professor assessments. 


\section{Discussion}

The average of empirical studies per year the last decade from 2008-2018 that examined the results of implementation of student self-assessment in Higher education, the ability of students to self-assess accurately and the factors that affect this ability is $(\mathrm{N}=3)$. Most of the studies are from international area $(\mathrm{N}=33)$. Spain is the country with most studies $(\mathrm{N}=7)$, whereas in Greece it was found only one research.

Analytically, the findings of the present study indicate that internationally, student self-assessment is implemented through a variety of ways and has positive effect mainly on learning and performance. Specifically, in the field of electronic self-assessment, e-portfolio promotes self-assessment and encourages self-directed language learning (Hung, 2009), on line self-assessment tool helps students fill knowledge gaps, improves performance as students can practice exam questions (Leaf et al., 2009) and encourages life-long and self-directed learning habits (Bhandary et al., 2016). Moreover, self-assessment material with Hot-Potatoes (Ibabe \& Jauregizar, 2010), on-line self-assessment test (Ćukušić et al., 2014) and web based mobile assessment improve academic performance (Chen, 2010), whereas self-assessment system helps students in their individual learning and prepares them for future test (Antal \& Koncz, 2011). Online self-assessment quiz taking behaviors increases perceived learning and improves performance (Ozarslan \& Ozan, 2016), whereas electronic rubrics reinforce learning and academic performance (Rivas \& Arrufat, 2016). Regarding the above research evidence of this review, digital self-assessment tools can be implemented in the context of student self-assessment in Higher education and have positive outcomes on students. Harris and Brown (2018) underlines that electronic self-assessment can be a very interesting and promising space for student self-assessment and there is need for further investigation.

Both peer and self-assessment help students receive feedback on their knowledge, understanding and skills they have developed (Duers, 2013), contribute to the shift of student learning method from surface to deep approaches to learning (Li \& Chen, 2016), improve learning and promote student responsibility towards learning (Ndoye, 2017). Rubrics promote the use of learning strategies and improve performance (Panadero \& Romero, 2014), whereas the process of co-creating rubrics may activate learning strategies and have a positive effect on performance (Fraile et al., 2017), whereas the implementation of a systematic cycle where self-assessment is applied as formative assessment source makes students set learning commitments, use learning strategies and identify weaknesses and strengths in their learning (Duque Micán \& Cuesta Medina, 2017). This finding is consistent with the finding in Ross (2006) where self-assessment helps students identify strengths and weaknesses in their work. Moreover, exemplars, provision of feedback and use of criteria as parts of self-assessment procedure improve performance (McKevitt, 2016), whereas the self-assessment sheet and the post-study feedback form help students make surface and meaning revisions of their work (Elgadal, 2017). In general, implementation of self-assessment process leads to higher academic performance and enhances learning (Sharma et al., 2016). From the above research evidence of this review, improvement of performance has also been identified by Rolheiser and Ross (2001), Ross (2006), McMillan and Hearn (2008) and Wride (2017).

Furthermore, web based self-assessment tool motivates students to ask guidance from their professors and help from their peers (Bhandary et al., 2016), whereas self-assessment within the framework of Biggs' 3P learning model develops self-regulating learning and increases self-confidence (Tai, 2012). Still, scripts (Panadero et al., 2013), and involvement of students in creation of rubrics contribute to the development of self-regulating learning (Fraile et al., 2017), whereas continuous self-assessment increases importantly self-efficacy (Alishah \& Dolmaci, 2013). Findings also show that student self-assessment in the process of co-teaching contributes to problem-solving, increases students' awareness of self-assessment ability and self-control and makes students change attitudes towards the course and recognize the importance and contribution of it to their learning (Wollfensperger \& Patkin, 2013). Still, electronic rubrics foster responsibility (Rivas \& Arrufat, 2016), whereas self and peer assessment prepare employability skills of students and make them be competitive in labor market (Machera, 2017), reduce anxiety for assessment, increase students' responsibility about their learning and make them have a critical view on their work and the work of their peers (Gurbanov, 2016). Moreover, self-assessment contributes to the development of critical thinking skills (Sharma et al., 2016). In Greece, it was found only one study where the quiz report analysis for moodle which is used for presenting student self-assessment results helped students improve their performance and self-regulation. Besides, it motivated students to try more and helped them identify gaps in their learning (Pournias, 2009). Some of the previous findings such as decrease of student anxiety has also highlighted by Wride (2017), whereas enhancement of motivation has also underlined by Rolheiser and Ross (2001) and McMillan and Hearn (2008) and enhancement of self-efficacy has also identified by Rolheiser and Ross (2001). Alonso-Tapia and Panadero (2010) mention that there are not many studies that examine the impact of student self-assessment on self-regulation and the present study confirms that as there are a few studies that examine the self-regulation as an 
outcome of student self-assessment.

Internationally, findings of this review show that students in Higher education can self-assess accurately (Boud et al., 2013; McKevitt, 2016; Sharma et al., 2016). Self-assessment ability of tertiary students has also been confirmed by Sluijsmans et al. (1999). On the other hand, there are findings that show lack of self-assessment skills (Langan et al., 2008; Chen, 2010) or accuracy of self-assessment to a limited extend (Lew et al., 2010). Harris and Brown (2018) underline that self-assessment is a complicated practice to implement successfully in the class. Indeed, the findings of the present study indicates that at the beginning of student self-assessment students can have difficulty and display hesitation towards self-assessment procedure but students' awareness of development of self-assessment ability can be increased (Wolffensperger \& Patkin, 2013).

With regard to the findings of the present study self-assessment ability depends on specific factors. Especially, students who are advanced are more able to self-assess than students who are novices. Moreover, learning style is an important factor that influences this ability as visual, active, balanced, sequential, and sensing students are more accurate (Alaoutinen, 2012). Besides, weaker students have more difficulty to self-assess (Boud et al., 2013), so students who are academically capable can self-assess with higher accuracy than students who are less capable (Lew et al., 2010). Moreover, training in implementation of student self-assessment helps students self-assess accurately (Thawabieh, 2017) and this finding is in line with the finding in Ross (2006) where is supported that student training contributes to the enhancement of the strength of student self-assessment. Still, confidence and prior achievement are related to students' self-assessment accuracy, whereas students with low and high prior achievement are better self-assessors than students with moderate prior achievement (Hosein \& Harle, 2018). Furthermore, scaffolding from professors, dialogical interaction and dynamic assessment help students to be better self-assessors (Alemi, 2015), whereas, gender is a factor that influences self-assessment ability as women seem to underestimate their performance when they self-assess (Langan et al., 2008). On the other hand, time and students' beliefs about the utility of the process of self-assessment don't influence accuracy of student self-assessment (Lew et al., 2010). Besides, with regard to relationship between student self-assessment ability and experience, there wasn't found any significance difference between students who had past experience with assessment procedures and students who were inexperienced (Sasmaz Oren, 2012). Some of the above findings that are associated with factors that influence self-assessment ability such as, gender, teach scaffolding and progress of students agree with previous literature (Topping, 2003). In Greece there is no research that examines student self-assessment ability and the factors that influence this ability in Higher education.

\section{Conclusions}

Most of the studies that examined the outcomes of the implementation of student self-assessment in Higher education, the ability of students to self-assess accurately and the factors that affect this ability are from international area whereas in Greece it was found only one research that examined the impact of student self-assessment on students. Moreover, the average of studies per year is 3 and Spain is the country with most studies.

Specifically, internationally, most studies have examined and proved the contribution of student self-assessment to improvement of performance and learning with very interesting and important findings. Self-assessment has been implemented through various ways that include inter alia electronic or non-electronic self-assessment tools. Still, self-assessment has been implemented in the context of learning models or with other practices such as co-teaching or peer assessment.

Analytically, e-portfolio encourages self-directed language learning, whereas on line self-assessment tools help students fill knowledge gaps, improve performance and encourage life-long and self-directed learning habits. Moreover, self-assessment material with Hot-Potatoes, on-line self-assessment tests and web based mobile assessment improve academic performance. Still, self-assessment system helps students in their individual learning and prepares them for future test, whereas the online self-assessment quiz taking behaviors increases perceived learning of students and improves performance. Besides, electronic rubrics reinforce learning and academic performance.

Both peer and self-assessment help students receive feedback on their knowledge, understanding and skills they have developed, shift student learning methods from surface to deep approaches to learning, improve learning and promote student responsibility towards learning. Furthermore, rubrics promote the use of learning strategies and improve performance, whereas web based self-assessment tool can motivate students to ask guidance from their professors and help from their peers. Co-creating rubric may activate learning strategies and have a positive effect on performance whereas the implementation of a systematic cycle where self-assessment is applied as formative 
assessment source makes students use learning strategies, set learning commitments and identify weaknesses and strengths in their learning. Moreover, exemplars, provision of feedback and use of criteria as parts of self-assessment process improve performance, whereas the self-assessment sheet and the post-study feedback form help students make surface and meaning revisions on their work.

Self-assessment within the framework of Biggs' 3P learning model develops self-regulating learning and increases self-confidence. Besides, scripts and involvement of students in creation of rubrics develop self-regulation learning. Still, continuous self-assessment increases significantly self-efficacy. Self-assessment within the context of co-teaching contributes to problem-solving, increases student awareness of self-assessment ability and self-control and makes students change attitudes towards the course and recognize the importance and contribution of it to their learning. Furthermore, electronic rubrics foster responsibility, whereas both self and peer assessment prepare employability skills of students and help them be competitive in labor market, reduce anxiety for assessment, increase students' responsibility about their learning and make them have a critical view on their work and the work of their peers. Still, self-assessment contributes to the development of critical thinking skills.

In Greece it was found only one relevant research where implementation of student self-assessment through the quiz report analysis for moodle improved students' performance, self-regulation, motivated students to try more and helped them identify shortcomings in their learning.

Self-regulating learning, motivation, self-confidence, self-efficacy, self-control, employability skills and students' responsibility have not examined so much in the context of student self-assessment in Higher education. Hence, internationally and in Greece there is need for more investigation of these variables as research has focused more on the impact of student self-assessment on learning and performance. This review reveals that electronic self-assessment is an upcoming research issue of student self-assessment internationally and in Greek Higher education. Besides, the positive outcomes of student self-assessment in Higher education lead to the conclusion that this type of assessment should be implemented more systematically because helps students not only within the context of their studies but also later in their working life providing them with necessary skills.

Student self-assessment ability and the factors that affect this ability have been examined only internationally so in Greece there is a research gap concerning these parameters. Students may have difficulty and show hesitation with self-assessment because it is a complicated process, however students' awareness of development of self-assessment ability can be increased. Tertiary students can self-assess accurately and this ability depends on specific factors. Analytically, students who are advanced are more able to self-assess than students who are novices and learning style seems to influence self-assessment ability as visual, active, balanced, sequential, and sensing students are more accurate. Still, students who are academically capable can self-assess with higher accuracy than students who are less capable. Moreover, students with low and high prior achievement are better self-assessors than students with moderate prior achievement. Confidence, prior achievement, scaffolding from professors, training, dialogical interaction and dynamic assessment are related to students' self-assessment accuracy. Besides, gender is a factor that influences self-assessment ability, as women seem to underestimate their performance when they self-assess. On the other hand, time, beliefs about the utility of the process of self-assessment are factors that don't influence accuracy of student self-assessment, whereas there is research evidence where students who have experience with assessment procedures don't differentiate from students who don't have experience.

\section{Limitations and Proposals for Further Research}

The present study has several limitations. First, the search of the examined studies is limited to specific bases of data and search machines and second, the review focuses only on tertiary students.

For future research, it is necessary to investigate the student self-assessment ability and the factors that affect this ability in Greek Higher education as there is research gap. Besides, examination of the contribution of student self-assessment to self-regulating learning, self-efficacy and employability skills in Greek Higher education is needed.

Additional studies to understand more completely the factors that affect student self-assessment ability are also required. Furthermore, there is need for empirical studies that will examine the effect of new electronic self-assessment tools on students in Higher education. Moreover, studies that will compare the results of electronic and non-electronic student self-assessment tools and examine the characteristics of these tools, the ease and frequency of their use could be interesting. 


\section{References}

Alaoutinen, S. (2012). Evaluating the effect of learning style and student background on self-assessment accuracy. Computer Science Education, 22(2), 175-198. https://doi.org/10.1080/08993408.2012.692924

Alemi, M. (2015). The Impact of Dynamic Assessment on Iranian EFL Students' Writing Self-Assessment. TELL, $9(1), 145-169$.

Alishah, A. R., \& Dolmaci, M. (2013). The interface between self-efficacy concerning the self-assessment on students studying English as a foreign language. Procedia-Social and Behavioral Sciences, 70(2013), 873-881. https://doi.org/10.1016/j.sbspro.2013.01.133

Alonso-Tapia, J., \& Panadero, E. (2010). Effects of self-assessment scripts on self-regulation and learning. Infancia y Aprendizaje, 33(3), 385-397. https://doi.org/10.1174/021037010792215145

Andrade, H., \& Valtcheva, A. (2009). Promoting learning and achievement through self-assessment. Theory into practice, 48(1), 12-19. https://doi.org/10.1080/00405840802577544

Antal, M., \& Koncz, S. (2011). Student modeling for a web-based self-assessment system. Expert Systems with Applications, 38(6), 6492-6497. https://doi.org/10.1016/j.eswa.2010.11.096

Bhandary, S., Ghimire, S. R., \& Shrestha, I. (2016). Evaluation of web-based self-assessment module administered in a medical school of Nepal. Journal of Patan Academy of Health Sciences, 1(2), 58-63. http://dx.doi.org/10.3126/jpahs.v1i2.20184

Boud, D., Lawson, R., \& Thompson, D. G. (2013). Does student engagement in self-assessment calibrate their judgement over time? Assessment \& Evaluation in Higher Education, 38(8), 941-956. http://dx.doi.org/10.1080/02602938.2013.769198

Brown, G. T., Andrade, H. L., \& Chen, F. (2015). Accuracy in student self-assessment: directions and cautions for research. Assessment in Education: Principles, Policy \& Practice, 22(4), 444-457. https://doi.org/10.1080/0969594X.2014.996523

Chen, C. H. (2010). The implementation and evaluation of a mobile self-and peer-assessment system. Computers \& Education, 55(1), 229-236. https://doi.org/10.1016/j.compedu.2010.01.008

Ćukušić, M., Garača, Ž., \& Jadrić, M. (2014). Online self-assessment and students' success in higher education institutions. Computers \& Education, 72(2014), 100-109. https://doi.org/10.1016/j.compedu.2013.10.018

Domínguez, C., Jaime, A., Sánchez, A., Blanco, J. M., \& Heras, J. (2016). A comparative analysis of the consistency and difference among online self-, peer-, external-and instructor-assessments: The competitive effect. Computers in Human Behavior, 60(2016), 112-120. https://doi.org/10.1016/j.chb.2016.02.061

Duers, L. E. (2013). "To see oursels as ithers see us!": an exploration of student nurses' conceptions and implementation of peer review and self-assessment (Doctoral dissertation, University of Strathclyde, Glasgow). Retrieved from http://oleg.lib.strath.ac.uk/R/?func=dbin-jump-full\&object_id=22643

Duque Micán, A., \& Cuesta Medina, L. (2017). Boosting vocabulary learning through self-assessment in an English language teaching context. Assessment \& Evaluation in Higher Education, 42(3), 398-414. https://doi.org/10.1080/02602938.2015.1118433

Elgadal, H. A. (2017). The effect of self-assessment on inexperienced EFL students'writing during revision (Doctoral dissertation, University of Birmingham, Birmingham). Retrieved from http://etheses.bham.ac.uk/7558/

Fraile, J., Panadero, E., \& Pardo, R. (2017). Co-creating rubrics: The effects on self-regulated learning, self-efficacy and performance of establishing assessment criteria with students. Studies in Educational Evaluation, 53(2017), 69-76. https://doi.org/10.1016/j.stueduc.2017.03.003

Gurbanov, E. (2016). The Challenge of Grading in Self and Peer-Assessment (Undergraduate Students' and University Teachers' Perspectives). Journal of Education in Black Sea Region, 1(2), 82-91.

Harris, L. R., \& Brown, G. T. (2018). Using Self-Assessment to Improve Student Learning. New York: Routledge. https://doi.org/10.4324/9781351036979

Hosein, A., \& Harle, J. (2018). The relationship between students' prior mathematical attainment, knowledge and confidence on their self-assessment accuracy. Studies in Educational Evaluation, 56(2018), 32-41. https://doi.org/10.1016/j.stueduc.2017.10.008 
Hung, S. (2009). Promoting self-assessment strategies: An electronic portfolio approach. Asian EFL Journal, 11(2), 129-146.

Ibabe, I., \& Jauregizar, J. (2010). Online self-assessment with feedback and metacognitive knowledge. Higher Education, 59(2), 243-258. https://doi.org/10.1007/s10734-009-9245-6

Keane, L., \& Griffin, C. P. (2016). Testing the limits of self-assessment: A critical examination of the developmental trajectories of self-assessment processes. Irish Teachers' Journal, 3(2), 1-23.

Langan, A. M., Shuker, D. M., Cullen, W. R., Penney, D., Preziosi, R. F., \& Wheater, C. P. (2008). Relationships between student characteristics and self, peer and tutor evaluations of oral presentations. Assessment \& Evaluation in Higher Education, 33(2), 179-190. https://doi.org/10.1080/02602930701292498

Leaf, D. E., Leo, J., Leaf, D. E., Leo, J., Smith, P. R., Yee, H., \& Pillinger, M. H. (2009). SOMOSAT: Utility of a web-based self-assessment tool in undergraduate medical education. Medical teacher, 31(5), 211-219. https://doi.org/10.1080/01421590802650118

Lew, M. D., Alwis, W. A. M., \& Schmidt, H. G. (2010). Accuracy of students' self-assessment and their beliefs about its utility. Assessment \& Evaluation in Higher Education, 35(2), 135-156. https://doi.org/10.1080/02602930802687737

Li, Y., \& Chen, L. (2016). Peer-and self-assessment: A Case Study to Improve the Students' Learning Ability. Journal of Language Teaching and Research, 7(4), 780-787. https://doi.org/10.17507/j1tr.0704.20

Logan, B. (2015). Reviewing the Value of Self-Assessments: Do They Matter in the Classroom? Research in Higher Education Journal, 29(2015), 1-11.

Machera, R. P. (2017). Teaching Intervention Strategies that Enhance Learning in Higher Education. Universal Journal of Educational Research, 5(5), 733-743. https://doi.org/10.13189/ujer.2017.050505

McKevitt, C. T. (2016). Engaging Students with Self-Assessment and Tutor Feedback to Improve Performance and Support Assessment Capacity. Journal of University Teaching and Learning Practice, 13(1), 1-20.

McMillan, J. H., \& Hearn, J. (2008). Student self-assessment: The key to stronger student motivation and higher achievement. Educational Horizons, 87(1), 40-49.

Ndoye, A. (2017). Peer/Self-Assessment and Student Learning. International Journal of Teaching \& Learning in Higher Education, 29(2), 255-269.

Ozarslan, Y., \& Ozan, O. (2016). Self-Assessment Quiz Taking Behavior Analysis in an Online Course. European Journal of Open, Distance and E-learning, 19(2), 15-31. https://doi.org/10.1515/eurodl-2016-0005

Panadero, E., \& Alonso-Tapia, J. (2013). Self-assessment: theoretical and practical connotations, when it happens, how is it acquired and what to do to develop it in our students. Electronic Journal of Research in Educational Psychology, 11(2), 551-576. https://doi.org/10.14204/ejrep.30.12200

Panadero, E., Alonso-Tapia, J., \& Reche, E. (2013). Rubrics vs. self-assessment scripts effect on self-regulation, performance and self-efficacy in pre-service teachers. Studies in Educational Evaluation, 39(3), 125-132. http://dx.doi.org/10.1016/j.stueduc.2013.04.001

Panadero, E., \& Romero, M. (2014). To rubric or not to rubric? The effects of self-assessment on self-regulation, performance and self-efficacy. Assessment in Education: Principles, Policy \& Practice, 21(2), 133-148. http://dx.doi.org/10.1080/0969594X.2013.877872

Panadero, E., Brown, G. T., \& Strijbos, J. W. (2016). The future of student self-assessment: a review of known unknowns and potential directions. Educational Psychology Review, 28(4), 803-830. http://dx.doi.org/10.1007/s10648-015-9350-2

Panadero, E., Jonsson, A., \& Botella, J. (2017). Effects of self-assessment on self-regulated learning and self-efficacy: Four meta-analyses. Educational Research Review, 22(2017), 74-98. http://dx.doi.org/10.1016/j.edurev.2017.08.004

Papageorgiou, K. A. (2017). Alternative evaluation proposals for primary education. Retrieved from https://eproceedings.epublishing.ekt.gr/index.php/openedu/article/view/1120

Petropoulou, O., Kasimati, A., \& Retalis, S. (2015). Contemporary educational assessment with the use of educational technologies. Retrieved from http://hdl.handle.net/11419/233 
Pournias, A. (2009). Expanding the moodle learning management system to present students self-assessment results (Master's thesis, University of Piraeus, Piraeus). Retrieved from http://dione.lib.unipi.gr/xmlui/bitstream/handle/unipi/3080/Pournias.pdf?sequence=3\&isAllowed=y

Rivas, M. R., \& Arrufat, M. J. G. (2016). University Students' Perceptions of Electronic Rubric-Based Assessment. Digital Education Review, 2016(30), 220-233.

Rolheiser, C., \& Ross, J. A. (2001). Student self-evaluation: What research says and what practice shows. Retrieved from

http://csimmonds.pbworks.com/w/file/fetch/118283790/Student\%20Self\%20Evaluation\%20What\%20Research $\% 20$ Says $\% 20$ and $\% 20$ What $\% 20$ Practice $\% 20$ Shows.pdf

Ross, J. A. (2006). The reliability, validity, and utility of self-assessment. Practical Assessment, Research \& Evaluation, 11(10), 1-13.

Sasmaz Oren, F. (2012). The effects of gender and previous experience on the approach of self and peer assessment: a case from Turkey. Innovations in Education and Teaching International, 49(2), 123-133. http://dx.doi.org/10.1080/14703297.2012.677598

Sebba, J., Crick, R. D., Yu, G., Lawson, H., Harlen, W., \& Durant, K. (2008). Systematic review of research evidence of the impact on students in secondary schools of self and peer assessment. Retrieved from https://eppi.ioe.ac.uk/cms/Default.aspx?tabid=2415

Sharma, R., Jain, A., Gupta, N., Garg, S., Batta, M., \& Dhir, S. K. (2016). Impact of self-assessment by students on their learning. International Journal of Applied and Basic Medical Research, 6(3), 226-229. http://dx.doi.org/10.4103\%2F2229-516X.186961

Sluijsmans, D., Dochy, F., \& Moerkerte G. (1999). The use of self-, peer and co-assessment in higher education: A review. Studies in Higher education, 24(3), 331-350. https://doi.org/10.1080/03075079912331379935

Tai, C. (2012). Undergraduate business and management students' experiences of being involved in assessment (Doctoral dissertation, University of Edinburgh, Edinburgh). Retrieved from https:/ethos.bl.uk/OrderDetails.do;jsessionid=D8EE10FF41129CC9A3069A915772E887?uin=uk.bl.ethos.6208 44

Thawabieh, A. M. (2017). A Comparison between Students' Self-Assessment and Teachers' Assessment. Journal of Curriculum and Teaching, 6(1), 14-20. http://dx.doi.org/10.5430/jct.v6n1p14

Topping, K. (2003). Self and peer assessment in school and university: Reliability, validity and utility. In: Segers M., Dochy F., Cascallar E. (eds.), Optimising New Modes of Assessment: In Search of Qualities and Standards. Innovation and Change in Professional Education, vol 1. Springer, Dordrecht. https://doi.org/10.1007/0-306-48125-1_4

Wolffensperger, Y., \& Patkin, D. (2013). Self-assessment of self-assessment in a process of co-teaching. Assessment \& Evaluation in Higher Education, 38(1), 16-33. http://dx.doi.org/10.1080/02602938.2011.596925

Wride, M. (2017). Assessment: Guide to Self-Assessment. Retrieved from https:/www.tcd.ie/CAPSL/assets/pdf/Academic\%20Practice\%20Resources/Guide\%20to\%20Student\%20Self\% 20Assessment.pdf 